\title{
Ruralidades e Política Ambiental: heterogeneidade socioeconômica e lógicas indiferenciadas dos projetos públicos de pagamento por serviços ambientais ${ }^{1,2}$
}

\author{
Rafael Eduardo Chiodi ${ }^{3}$, Paulo Eduardo Moruzzi Marques ${ }^{4}$ e \\ Roldan Sarache Muradian ${ }^{5}$
}

\begin{abstract}
Resumo: As novas ruralidades têm como uma das principais características a heterogeneidade socioeconômica e sociocultural construídas pela convivência entre agricultores e novos moradores dos espaços rurais. Como proprietários rurais, ambos se tornam público-alvo de novas políticas ambientais, especialmente aquelas de pagamento por serviços ambientais para a conservação dos recursos hídricos (PSA-Água). O trabalho analisa o componente central do PSA-Água, o pagamento financeiro, sob o ângulo da equidade na distribuição de recursos financeiros em contextos de novas ruralidades. Em 2013, foram entrevistados 77 proprietários rurais participantes em três dos principais projetos brasileiros de PSA-Água. Os projetos foram implementados onde proprietários rurais apresentam perfis socioeconômicos diferenciados. O grau de dependência da família em relação à propriedade rural para sua reprodução social é central para esta diferenciação. Os projetos destinaram maiores montantes aos proprietários menos dependentes da propriedade, mas promoveram, proporcionalmente à renda, transferências mais significativas aos mais dependentes. Entretanto, duas principais características dos desenhos dos projetos favorecem a invisibilidade da heterogeneidade socioeconômica e sociocultural das realidades rurais para transferir os pagamentos: primeiro, priorizar dimensões ambientais para definir o valor do pagamento e; segundo, assumir indiferenciadamente o estatuto de proprietário rural como público-alvo dos projetos.
\end{abstract}

Palavras-chaves: ruralidades, política ambiental, agricultura familiar, serviços ambientais.

Abstract: The new ruralities have as a major feature a high degree of socio-economic and sociocultural heterogeneity, based on the coexistence of farmers and new residents in rural areas. As

1. Data de submissão: 7 de junho de 2016. Data de aceite: 18 de março de 2018.

2. Os autores agradecem o apoio financeiro da Fundação de Amparo à Pesquisa do Estado de São Paulo e do Conselho Nacional de Desenvolvimento Científico e Tecnológico.

3. Universidade Federal de Lavras. Lavras, MG, Brasil. E-mail: rafaelchiodi@yahoo.com.br

4. Escola Superior de Agricultura "Luiz de Queiroz". Piracicaba, SP, Brasil. E-mail: pmarques@usp.br

5. Universidade Federal Fluminense. Niterói, RJ, Brasil. E-mail: roldanmuradian@gmail.com 
landowners, both become the target of new environmental policies, including payment for water-related ecosystem services (PSA-Water). The paper analyzes the central component of PSA-Water, the payment, from the perspective of equity in the distribution of financial resources in the context of new ruralities. In 2013, we interviewed 77 farmers participating in three major Brazilian projects of PSA-Water. The projects were implemented in areas where landowners have different socioeconomic profiles. The degree of dependence on the rural property for the social reproduction of the household is a central component of this differentiation. PSA projects allocated larger amounts to landholders less dependent on the property for their livelihoods, but proportionally to the income of the households, contributed more to landholders more dependent on their lands. Two features of the design of projects tend to make invisible the heterogeneity of landholders. First, to adopt mainly environmental criteria to define the amount of the payment; and second, to take being a landholder (any type) as the main criterion for eligibility.

Key-words: ruralities, environmental politics, family farm, environmental services.

Classificação JEL: O13, O38.

DOI: http://dx.doi.org/10.1590/1234-56781806-94790560204

\section{Introdução}

Nas últimas décadas, a concepção de um rural estritamente agrícola vem passando por mudanças profundas. As transformações das realidades rurais apontam para a valorização de uma conjunção de componentes de natureza social, ambiental, econômica e cultural. Portanto, há em curso uma mutação da visão do rural enquanto lugar estritamente produtivo com função unicamente econômica para outra segundo a qual o rural é considerado como um território com múltiplos papéis para a sociedade global (GRAZIANO DA SILVA, 1999; MALUF, 2003; CARNEIRO, 2012).

Um dos fatores promotores destas transformações socioeconômicas e socioculturais é o fenômeno da instalação de novos moradores e da frequentação de novos usuários no espaço rural, em especial os provenientes do meio urbano (GRAZIANO DA SILVA, 1999; CARNEIRO, 2012). Para Graziano da Silva (1999), esse fenômeno cria um "novo rural" em localidades próximas aos grandes centros urbanos, o que permite caracterizar o fenômeno como uma "urbanização do rural". Nesses espaços, Maria J. Carneiro (2012) identifica a configuração de "ruralidades contemporâneas", construídas justamente pela inter-relação entre antigos e novos moradores que caracterizam a heterogeneidade social deste novo rural.

As variáveis explicativas para a configuração das novas ruralidades são numerosas, mas uma de grande relevância é a emergência da questão ambien- tal. Porém, esta última também pode ser entendida sob diferentes ângulos de visão. Aqui, ressalta-se a emergência de uma representação social que vincula o rural à natureza, o que vem atraindo cidadãos urbanos ao espaço rural. Por outro lado, as preocupações com a conservação dos recursos naturais levam à concepção de novas políticas de conservação destinadas às novas localidades rurais. Exemplo emblemático de tal fenômeno pode ser visto no meio rural dos municípios paulistas e mineiros que englobam a área de contribuição dos reservatórios de um dos principais sistemas de abastecimento de água do País, o Sistema Cantareira (UEZU et al., 2012).

Com efeito, as políticas ambientais recaem sobre contextos socioeconômicos heterogêneos, o que deve ser considerado em primeiro plano para a análise de seus efeitos, em particular aqueles da aplicação de um novo instrumento, o mecanismo de pagamento por serviços ambientais (PSA). Trata-se do pagamento financeiro para agentes privados como meio para alcançar a conservação ambiental. Desse modo, convém examinar este dispositivo cuja lógica é de apropriação individual de recursos sociais por uma ótica de equidade distributiva. Nesta perspectiva, torna-se relevante a noção de justiça ambiental para a reflexão e o debate na sociedade brasileira sobre as políticas que distribuem benefícios gerados pela proteção ambiental (NUSDEO, 2012).

Desde 2005, as políticas relacionadas ao conceito de serviços ambientais vêm ganhando relevância em 
âmbito internacional e nacional, em grande medida, pela publicação da Avaliação dos Ecossistemas do Milênio The Millennium Ecosystem Assessment/MA. A MA trouxe este conceito para avaliar as consequências das mudanças dos ecossistemas para o bem-estar humano e estabeleceu bases científicas para ações consideradas necessárias à conservação e ao uso sustentável dos ecossistemas e dos seus serviços (MA, 2005). Os serviços ambientais foram concebidos como as intervenções que favorecem as condições e os processos pelos quais os ecossistemas mantêm suas funções e sustentam a vida humana (DAILY, 1997). O pagamento por serviços ambientais (PSA) foi um dos novos mecanismos escolhidos para paralisar e reverter os processos de degradação dos serviços ecossistêmicos. O mecanismo de PSA pode ser definido como uma transferência de recursos entre atores sociais, que objetiva criar incentivos para alinhar decisões individuais ou coletivas de uso da terra com o interesse social na gestão de recursos naturais (MURADIAN et al., 2010).

No Brasil, o mecanismo de pagamento por serviços ambientais para a conservação dos recursos hídricos (PSA-Água) ganhou destaque na última década. Das 18 principais inciativas de PSA compiladas em Pagiola, Glehn e Taffarello (2013), 13 delas são vinculadas ao PSA-Água. Grande parte das iniciativas se insere na esfera de políticas estaduais e municipais de gestão de recursos hídricos. Por meio da elaboração de leis e da regulamentação por decretos viabilizando uma existência legal, estes poderes executivos criam formas de funcionamento, financiamento e controle para o mecanismo de PSA-Água.

A partir de 2006, o uso do mecanismo de PSAÁgua conhece uma expansão significativa após o lançamento do Programa Produtor de Água da Agência Nacional das Águas (ANA). Destinado prioritariamente às áreas críticas de mananciais hídricos, tal programa tem como objetivo controlar a poluição difusa em bacias hidrográficas, fomentando ações para reduzir a erosão do solo, melhorar a qualidade da água e regular o regime hidrológico de rios. O programa difunde as diretrizes do modelo "Produtor de Água", dentre as quais: a) utilizar o mecanismo de PSA, b) ser aplicado em áreas rurais, visando, preferencialmente, pequenos proprietários rurais, c) usar a bacia hidrográfica como unidade de planejamento e execução, d) privilegiar práticas sustentáveis de produção e e) implementar sistemas de monitoramento de resul- tados (ANA, 2013). Com base no modelo "Produtor de Água", são concebidos os principais projetos públicos que mobilizam o mecanismo de PSA-Água. Dentre os pioneiros, estão o Conservador das Águas, em Extrema (MG), o ProdutorES de Água, em Alfredo Chaves (ES), e o Projeto Piloto Produtor de Água nas Bacias dos Rios Piracicaba, Capivari e Jundiaí, em Nazaré Paulista e Joanópolis (SP).

Nos contextos de aplicação desses projetos, o artigo veicula uma análise sobre o componente central do mecanismo de PSA-Água, o pagamento financeiro, sob o ângulo da equidade na distribuição de recursos financeiros via política pública ambiental. Nesta perspectiva, trata-se de discutir o seguinte problema de pesquisa: para quais categorias sociais e em quais proporções são destinados os fundos do dispositivo PSAÁgua? O artigo se estrutura da seguinte maneira: a seção 2 trata da sustentação teórica da pesquisa, apresentando as vinculações entre as novas ruralidades e as mais recentes políticas ambientais. A seção 3 refere-se à metodologia empregada na pesquisa. Na seção 4 , são descritas brevemente as características das localidades onde os projetos ocorrem e os esquemas de pagamento estabelecidos. Na seção 5, delimita-se uma diferenciação de perfis socioeconômicos dos proprietários rurais beneficiados pelos projetos. Na seção 6, são discutidas as transferências monetárias efetuadas via PSA por perfil com base na noção de justiça ambiental. Na seção 7, analisa-se a importância do PSA para a renda familiar, discutindo os impactos sobre cada perfil de proprietário rural.

\section{As novas ruralidades e a questão ambiental}

O estudo de Graziano da Silva (1999) evidenciou transformações no meio rural brasileiro que despertaram para novas formas de analisá-lo, em especial aqueles próximos às regiões industrializadas e intensamente urbanizadas. O "novo rural" identificado por esse autor é aquele que não pode mais ser entendido como a expressão de atividades agropecuárias e agroindustriais, pois abriga cada vez mais atividades não agrícolas e famílias menos dedicadas à agropecuária. Para o autor, este fenômeno pode ser identificado como uma "urbanização do rural", caracterizada, em parte, pela expansão de casas de moradia, pela disponibilidade de 
242 - Ruralidades e Política Ambiental: heterogeneidade socioeconômica e lógicas indiferenciadas dos projetos públicos de pagamento por serviços ambientais

novas atividades e serviços e pela melhoria nas condições de acesso e comunicação, o que permite, em certa medida, o estabelecimento da população urbana em meio rural. $\mathrm{O}$ autor afirma que o dinamismo econômico gerado pela ampliação do mercado de trabalho nas áreas rurais devido à chegada de neo-rurais induz a pensar em uma revitalização do rural, em oposição ao seu esvaziamento pela migração da população para as cidades.

No campo sociológico, o fenômeno da emergência de neo-rurais também desperta interesses analíticos. Maria José Carneiro (2012) designou de "ruralidades contemporâneas" as localidades rurais nas quais ocorre uma reestruturação dos elementos da cultura local mediante a incorporação de novos valores, hábitos e técnicas. A heterogeneidade social é a marca das novas ruralidades, expressa nas diferentes formas de representação social e de apropriação dos bens materiais e simbólicos das localidades rurais. As inter-relações entre antigas e novas finalidades do rural, ou, mais especificamente, da família e da propriedade rural, são componentes destas novas ruralidades. Se por um lado, os espaços rurais se abrem a novas formas de conflitos e antagonismos socioculturais, por outro, permitem novas formas de interação social entre população rural e urbana (CARNEIRO, 2012).

As transformações socioeconômicas do "novorural" e aquelas socioculturais das "ruralidades contemporâneas" têm fatores explicativos diversos, que fogem ao propósito deste artigo. O nosso foco se dirige a um dos fatores mais importantes e recorrentes nas análises das novas ruralidades, a emergência da questão ambiental. Neste sentido, é importante realçar duas dimensões: 1) a emergência de uma representação social que vincula o rural à natureza, atraindo cidadãos urbanos ao espaço rural por motivos e valores diversos, contribuindo com sua heterogeneidade socioeconômica e 2) a ampliação das preocupações com a conservação dos recursos naturais essenciais ao desenvolvimento econômico e social leva à concepção de novas políticas de conservação ambiental para as localidades rurais.

A emergência da representação social de um rural próximo à natureza pode ser relacionada à própria construção social da valorização do mundo natural. Neste sentido, Diegues (2001) descreve a influência que a ideia de "paraíso", difundida pelo Cristianismo desde a Idade Média, como um lugar natural, belo e desabitado, teve sobre o paradigma da conservação por meio de áreas protegidas, representação que ainda influencia setores do conservacionismo moderno. No entanto, remonta ao começo da revolução industrial a valorização do rural como um mundo natural, em oposição às cidades associadas ao ambiente fabril, que provoca condições de vida insalubre devido à poluição. Assim, a vida rural passou a ser idealizada, sobretudo pelas classes sociais urbanas não diretamente envolvidas na produção agrícola. O crescimento populacional nas cidades inglesas teria também originado certo sentimento antissocial, favorecendo uma atitude de contemplação da natureza selvagem, lugar de reflexão e de isolamento espiritual (DIEGUES, 2001).

Para Froehlich e Monteiro (2002), a busca do contato com o meio natural, embasada pelo desejo dos citadinos em transformá-lo em mais um bem de consumo, embora se realize de várias formas, parece se guiar por uma peculiar associação do rural com a natureza. No Brasil, nas últimas décadas, a mídia tem consistentemente contribuído para fortalecer a imagem do meio rural vinculado ao mundo natural. Neste sentido, o mercado do turismo e do lazer ganha relevante destaque em meio rural (HOEFFEL, FADINI e SUAREZ, 2009). Almeida Jr. e Andrade (2007), estudando a relação entre consumo e sustentabilidade ambiental, afirmam que a sociologia ambiental e a do consumo detectam que é complexa a relação entre a busca de novos estilos de vida e a atenção à sustentabilidade ambiental, mas afirmam que, em termos de disposições e posturas direcionadas ao consumo de bens e serviços com apelo ambiental, a publicidade se torna um aspecto de extrema importância para compreender essa relação.

Desse modo, o rural pode se associar à natureza em campo semântico que envolve as noções de tranquilidade, ar puro, sossego, descanso, dentre outras noções refrigérias (FROEHLICH e MONTEIRO, 2002). Na Colômbia, Sastoque (2014) classificou 12 tipos de neo-rurais pela relação que estabelecem com as localidades rurais, sendo que praticamente todos comportam algumas das noções listadas acima. No Brasil, não há estudos amplos que mostrem e quantifiquem os motivos que levam os moradores urbanos a se fixarem nos espaços rurais. Porém, diversos trabalhos permitem entender a importância que a emergência da representação social de um rural ligado à natureza tem sobre o deslocamento de moradores urbanos para residirem em meio rural. Dentre estes estudos, destaca-se a já mencionada coletânea de trabalhos organizada 
por Carneiro (2012), sob o título de "Ruralidades Contemporâneas", que apresenta um conjunto de olhares analíticos principalmente realizados na região serrana do Rio de Janeiro, que demonstram a relevância da representação de natureza associado ao rural para os neo-rurais. O intenso turismo ambiental na região Bragantina, próxima à região metropolitana de São Paulo, também pode ser analisado por esta ótica (HOEFFEL, FADINI e SUAREZ, 2009).

Se a primeira dimensão mencionada corresponde à representação de um rural associado a uma natureza preservada em relação aos ambientes urbanos poluídos, a segunda dimensão emerge sobre a representação de uma natureza com problemas. O marco desta visão foi a realização da I Conferência das Nações Unidas para o Ambiente Humano em Estocolmo, em 1972, que inscreve a questão ambiental na agenda política mundial. No Brasil, seus reflexos foram pressões externas e internas que impulsionaram um movimento de expansão da ação governamental, refletindo na implementação de políticas públicas para tratar dos problemas ambientais (ACSELRAD, 2001). Neste contexto, as políticas públicas ganharam notoriedade por serem frutos de tomada de decisão que afetam a coletividade e condicionam o conjunto da sociedade (ASSUMPÇÃO RODRIGUES, 2010).

As principais políticas públicas e instituições criadas para tratar da questão ambiental priorizaram os instrumentos regulatórios, que se apoiam na regulamentação direta, acompanhada de fiscalização e sanção quando do não cumprimento das normas e padrões estabelecidos (NUSDEO, 2012). Neste quadro, o Código Florestal (CF) ganha importância como o principal instrumento de legislação que recai sobre o meio rural, pois visa conservar recursos naturais em propriedades rurais. O CF apresenta duas disposições centrais: um percentual da área da propriedade rural (20\% no bioma Mata Atlântica) deve ser mantido com vegetação nativa a título de Reserva Legal (RL) e a obrigatoriedade de manter as Áreas de Preservação Permanente (APP) existentes na propriedade, que incluem áreas ao longo dos cursos d'água (com larguras de 30 metros ou mais), em torno de nascentes (50 metros), topo de morros e terrenos com declividade maior ou igual a $45^{\circ}$ (BRASIL, 2012).

Instituído em 1965, o CF vigorou por 47 anos antes de sua alteração, em 2012, e claramente não cumpriu suas finalidades. Somente o passivo de Reserva Legal (diferença entre o estabelecido na lei e a porção protegida na prática) foi estimado em 159,3 milhões de hectares (61,7\% da área total, segundo o que prevê a lei). $\mathrm{O}$ passivo em pequenas propriedades rurais aproximou-se de 29,6 milhões de hectares (IPEA, 2011). Sparovek et al. (2011) estimaram que o passivo em Área de Preservação Permanente ao longo dos cursos d'água chega a 43 milhões de hectares, distribuídos por todas as regiões do País.

Com efeito, proprietários tanto de grandes e médias como de pequenas propriedades não cumprem totalmente essa legislação ambiental. Porém, utilizando o termo de Ascelrad (2010), a agricultura do tipo familiar, em muitos contextos, é vítima da "despossessão de recursos ambientais". Ou seja, a atividade agrícola familiar se pratica em estabelecimentos de tamanho reduzido, ocupam áreas desfavoráveis para a agricultura intensiva, em que predominam solos de menor fertilidade natural, em regiões montanhosas ou semiáridas. Por estas razões, é muito utilizado o espaço produtivo próximo aos cursos d'água, pois são mais férteis e planos. Trata-se, assim, de um meio para viabilizar as atividades produtivas e a reprodução social da família. Por tal comportamento e pela intensificação da fiscalização, esta categoria sofre com multas ambientais e com restrições produtivas, o que explica, em parte, a busca de novas oportunidades de trabalho não agrícola (CARNEIRO, 2012). Essa situação também reflete um generalizado conflito entre o objetivo da preservação dos recursos naturais e a prática da agricultura em pequenos estabelecimentos rurais, acentuado pelo modo de atuação dos órgãos de fiscalização ambiental, tal como foi apresentado em um conjunto de estudos de casos realizados em diferentes contextos da agricultura familiar no Brasil (MALUF, 2003).

Em certa medida, foi a partir do entendimento da ineficácia dos instrumentos regulatórios para alcançar a conservação ambiental e dos conflitos gerados por sua implementação, que ganham espaço nos últimos anos os instrumentos de incentivo econômico como o PSA (NUSDEO, 2012). Este último constitui um instrumento que visa remunerar voluntariamente os agentes que promovem a recuperação e a conservação dos serviços ambientais (ENGEL, PAGIOLA e WUNDER, 2008). Para tanto, o seu componente central, o pagamento direto, é apresentado como tendo a melhor relação entre custo financeiro e benefício ambiental diante de outros modelos de conservação, como 
244 - Ruralidades e Política Ambiental: heterogeneidade socioeconômica e lógicas indiferenciadas dos projetos públicos de pagamento por serviços ambientais

aqueles dos Projetos Integrados de Conservação e Desenvolvimento (FERRARO e KISS, 2002).

No Brasil, o mecanismo de PSA-Água está sendo aplicado via políticas públicas em diferentes regiões e biomas. Regra geral, estas iniciativas são implementadas em contextos socioeconômicos heterogêneos, em configurações das novas ruralidades, justamente por se destinarem à conservação de bacias hidrográficas responsáveis pelo abastecimento d'água de cidades industriais, portanto, em áreas rurais muito próximas de grandes centros urbanos. É o caso da área de contribuição do sistema Cantareira, onde se encontram em desenvolvimento quatro diferentes iniciativas de PSA-Água ${ }^{6}$. O dispositivo também é proposto em outras localidades com configurações semelhantes (PAGIOLA, GLHEN e TAFFARELLO, 2013).

Considerando-se que a agricultura de base familiar em pequenos estabelecimentos rurais historicamente enfrenta restrições impostas pela legislação ambiental regulatória, em especial a interdição do uso do solo de zonas ripárias para produção agrícola e reprodução social das famílias agrícolas, que a criação de um mecanismo que visa oferecer uma recompensa pelos esforços de observar tais restrições ganha relevância. Entretanto, o mecanismo de PSA-Água é proposto no momento e em locais onde os agricultores familiares passam a compartilhar o espaço rural com moradores menos dependentes da terra. Ambos como proprietários rurais têm as mesmas obrigações diante da legislação ambiental regulatória e passam a poder obter benefícios das novas políticas de incentivo econômico. Para discutir em que medida tais incentivos econômicos possam ser considerados justos neste quadro heterogêneo, a noção de justiça ambiental parece muito pertinente com vistas à análise desse mecanismo.

A noção de justiça ambiental é concebida primeiramente sob o ângulo de visão dirigido aos impactos gerados por situações de degradação do ambiente e de escassez de recursos naturais sobre os grupos sociais despossuídos e marginalizados. No entanto, também passou a ser tratada sob a ótica da equidade na distribuição dos benefícios gerados por novas formas de gestão, uso e manejo dos recursos naturais (ASCELRAD, 2010; NUSDEO, 2012). Neste sentido,

6. Conservador das Água em Extrema (MG), Bolsa Verde em Camanducaia (MG), Projeto Piloto no PCJ em Nazaré Paulista e Joanópolis (SP) e Mina D'água em Piracaia (SP). em sociedades como a brasileira, extremamente desigual em termos sociais, econômicos e políticos, a possibilidade de comunidades indígenas, tradicionais e grande parte dos agricultores familiares poderem ser retribuídos por participar da preservação ambiental merece ser profundamente estudada. Para tanto, a noção de equidade para a análise da recompensa pela preservação ambiental leva a considerar objetivos distributivos relacionados à fragilidade desses grupos. A equidade no âmbito dos resultados dos projetos de PSA-Água se relaciona com a distribuição de recursos públicos entre agentes privados, sob a ótica da justiça distributiva da apropriação individual de recursos sociais (NUSDEO, 2012).

Neste sentido, há um debate na literatura internacional sobre a qual deveria ser a abordagem essencial dos PSA. Para Wunder (2013), este mecanismo deveria ser essencialmente uma ferramenta de política ambiental, o que implica ter como objetivo central maximizar o impacto ambiental do pagamento, tendo como critério principal para a alocação dos pagamentos a provisão "adicional" (em relação ao cenário de não pagamento) de serviços ecossistêmicos pelos proprietários da terra. A partir dessa perspectiva, os critérios de eficiência e efetividade deveriam ter primazia. Esse tipo de desenho pode ter um efeito distributivo positivo, mas só se aqueles agentes com maior potencialidade de provisão de serviços ecossistêmicos são também os mais vulneráveis do ponto de vista socioeconômico (PAGIOLA, ARCENAS e PLATAIS, 2005). O argumento usado por estes autores é que a principal vantagem dos PSA é sua capacidade de compensar os custos de oportunidade e, assim, criar incentivos diretos para atingir metas ambientais. Se os pagamentos tivessem múltiplos objetivos, a efetividade seria comprometida. Para outros autores, porém, os PSA são necessariamente instrumentos de desenvolvimento rural. Portanto, devem considerar a equidade como uma dimensão fundamental no desenho dos pagamentos, inclusive para garantir que os objetivos ambientais sejam alcançados (PASCUAL et al., 2014). Um dos argumentos usados para justificar esta perspectiva é que considerar a dimensão de equidade é fundamental para obter legitimidade no desenho de políticas públicas e que o desenho de pagamentos não pode ser desvinculado da noção de justiça, particularmente em regiões caracterizadas por altos níveis de desigualdade. 


\section{Metodologia}

Para a pesquisa, foram escolhidos três casos por serem de destaque na implementação do mecanismo de PSA-Água e por representarem três níveis distintos de esferas públicas.

Em nível estadual, a pesquisa focou o projeto ProdutorES de Água, em Alfredo Chaves, no estado do Espírito Santo. Trata-se da implantação de um mecanismo de PSA-Água graças à primeira lei estadual que adere ao referencial de serviços ambientais. Tal lei prevê a criação do primeiro fundo estadual para financiar o PSA-Água (SOSSAI et al., 2012).

Em nível de Comitê de Bacia Hidrográfica, o projeto piloto Produtor de Água nas bacias dos rios Piracicaba, Capivari e Jundiaí, nos municípios de Joanópolis e Nazaré Paulista, no estado de São Paulo, marcou a implementação prática do modelo "Produtor de Água" em uma das bacias hidrográficas mais ameaçadas do País (ANA, 2013).

Em nível municipal, o projeto Conservador das Águas no município de Extrema no sul de Minas Gerais é o caso de maior destaque nacional, em razão de ser o primeiro projeto com base legal estabelecido no País, tendo alcançado resultados práticos amplos e significativos.

Na pesquisa de campo, o principal instrumento de investigação foi a entrevista semiestruturada. Um roteiro de entrevista composto por perguntas abertas e fechadas, como sugerido por Richardson (2010), foi elaborado e aplicado. Foram entrevistados proprietários rurais participantes dos projetos de PSA-Água. A denominação "proprietário rural" foi concebida como unidade de análise na medida em que assim são identificados os atores participantes dos projetos de PSA-Água. O "proprietário rural" é aquele que tem a propriedade formal da terra e usufrui de seus recursos disponíveis.

Em cada caso, procedeu-se a uma delimitação amostral dos proprietários rurais a serem entrevistados. A partir do número total de participantes (população) dos projetos de PSA-Água, estabeleceu-se uma amostra maior que $20 \%$ em todos os casos. Ao todo foram 77 entrevistas, sendo 30 em Alfredo Chaves (138 participantes), 15 em Nazaré Paulista e Joanópolis (41 participantes) e 32 em Extrema (144 participantes).

A escolha dos proprietários entrevistados partiu do princípio da aleatoriedade. A partir da lista de nomes e coordenadas dos proprietários rurais participantes, de modo aleatório, foram selecionados os entrevistados, desde que manifestassem interesse e disponibilidade. As entrevistas ocorreram entre julho e dezembro de 2013.

Desse modo, a principal base de dados foi, portanto, constituída por informações de caráter declaratório coletadas na pesquisa de campo por meio de entrevistas. Contudo, foram acessadas, quando necessário, informações de caráter documental.

Com base nestas informações declaradas, empreendeu-se uma classificação de perfis de proprietários rurais. A diferenciação do perfil dos proprietários levou em consideração quatro condições centrais: a) o local de residência da família; b) a origem da renda familiar; c) a dedicação da família, em tempo de trabalho, às atividades produtivas rurais próprias e d) a finalidade da produção agropecuária.

Para identificar os montantes transferidos pelos projetos aos proprietários, foram levantados dados sobre os valores no período do contrato, o que varia em cada projeto. A partir destes dados, calculou-se a transferência de modo absoluto e relativo considerando os perfis dos entrevistados. A renda familiar total foi estimada a partir da declaração dos principais rendimentos familiares. Por fim, o percentual do valor recebido pelo PSA-Água na renda familiar total foi obtido graças igualmente às declarações das famílias entrevistadas.

\section{Os locais e as intervenções}

\subsection{ProdutorES de Água em Alfredo Chaves (ES)}

O município de Alfredo Chaves faz parte da mesorregião central do estado do Espírito Santo e está localizado a 85 quilômetros da capital Vitória. O município é acentuadamente montanhoso e recebe um volume de chuvas entre 1.160 e $2.020 \mathrm{~mm}$ anuais. Em 2007, a cobertura florestal atlântica representava 49,9\% de todo o município. O território do município está totalmente inserido na bacia hidrográfica do rio Benevente (IEMA, 2013).

Em 2010, Alfredo Chaves contava 13.955 habitantes. Naquele ano, $47 \%$ da sua população ocupava a área urbana e 53\%, o meio rural (IBGE, 2011). Portanto, trata-se de município predominantemente rural, tendo na agricultura familiar a principal forma de organiza- 
246 - Ruralidades e Política Ambiental: heterogeneidade socioeconômica e lógicas indiferenciadas dos projetos públicos de pagamento por serviços ambientais

ção produtiva. As principais atividades rurais estão concentradas na cafeicultura, bananicultura, pecuária e na olericultura. Convém mencionar que o meio rural do munícipio apresenta diversos atrativos naturais (rios, cachoeiras e florestas preservadas), o que faz crescer as atividades voltadas ao turismo rural, resultando na disseminação de pousadas e sítios de lazer.

Foi neste município que o projeto ProdutorES de Água foi pioneiramente implementado pela Lei Estadual n. 8.995 de 23 de setembro de 2008. A lei propôs, como objetivos do PSA, recompensar financeiramente o proprietário rural em função do valor econômico dos serviços ambientais prestados por sua área de cobertura florestal. Estes serviços são: a) conservação e melhoria da qualidade e da disponibilidade hídrica; b) conservação e incremento da biodiversidade; c) redução dos processos erosivos; e d) fixação e sequestro de carbono para fins de minimização dos efeitos das mudanças climáticas globais (ESPÍRITO SANTO, 2008).

O desenvolvimento do projeto na bacia do rio Benevente começou em dezembro de 2008 com a convocação de proprietários rurais para, voluntariamente, integrarem o Programa de PSA. Ao todo foram assinados 138 contratos, nos quais o Estado empenhou R\$ 709.800,12 em três anos para manter 1.688,82 hectares de cobertura vegetal nativa na bacia (IEMA, 2013). Os contratos previam que os proprietários rurais deveriam manter a cobertura florestal sem qualquer tipo de intervenção, o que permitiria receber anualmente recursos do PSA, garantidos via Fundo Estadual de Recursos Hídricos do Espírito Santo, abastecido por 3\% dos royalties do petróleo e pelos royalties da água (compensações pagas pelas hidrelétricas).

O Instituto Estadual de Meio Ambiente e Recursos Hídricos do Espírito Santo (Iema) foi o órgão responsável pela operacionalização do projeto, cuja adesão foi orientada por critérios de elegibilidade: os proprietários deveriam possuir terras em zonas ciliares, em faixa de declividade igual ou superior a $20 \%$, e/ou com formação de cobertura florestal nativa do ecossistema regional, além de poder comprovar a posse da terra (ESPÍRITO SANTO, 2008). O valor de cada contrato variou conforme a área ocupada por vegetação ciliar ao longo de cursos d'água na propriedade, considerando até 100 metros de faixa de mata ciliar, a declividade do terreno e o estágio sucessional da cobertura florestal. No entanto, o valor mínimo de $\mathrm{R} \$ 246,34$ por hectare ao ano foi garantido com base no custo de oportunidade da terra ponderado para as principais culturas agrícolas do estado (BELOTE et al., 2008).

\subsection{Conservador das Águas em Extrema (MG)}

O município de Extrema faz parte da mesorregião sul de Minas Gerais, localizado a cerca de 490 quilômetros da capital Belo Horizonte e a 110 quilômetros da cidade de São Paulo. Situada na cadeia de montanhas da Serra da Mantiqueira, Extrema possui relevo com declives acentuados e precipitação média anual entre 1.600 e 1.800 mm. Em 2007, cerca de 34\% da área do município estava coberta por vegetação florestal (UEZU et al., 2012).

Extrema é um dos quatro municípios mineiros que integram os Comitês das Bacias Hidrográficas dos rios Piracicaba, Capivari e Jundiaí (Comitês PCJ). Praticamente toda sua área pertence à Bacia Hidrográfica do rio Jaguari, principal contribuidora do Sistema Produtor de Água Cantareira. Considerado um dos maiores do mundo, este último chega a abastecer aproximadamente nove milhões de pessoas na região metropolitana de São Paulo (RMSP). O projeto ocorre nas sub-bacias hidrográficas dos ribeirões das Posses e do Salto.

Em 2010, a população do município era de 28.599 habitantes. Desta população, 91\% residem em área urbana e 9\%, no meio rural (IBGE, 2011). O meio rural de Extrema é marcado pela atividade agropecuária, sendo que $62 \%$ do seu solo são ocupados por pastagens (UEZU et al., 2012). Predomina a pecuária bovina extensiva para produção de leite e carne que, apesar de não possuir mais a dinâmica de outros tempos, mantém relativa importância. Pela recente e intensa industrialização do município e pela proximidade a grandes cidades como São Paulo e Campinas, a presença de neo-rurais já se tornou um fenômeno consolidado.

Neste contexto, a Lei Municipal n. 2.100, de 21 de dezembro de 2005 foi homologada, o que permitiu a criação do projeto Conservador das Águas. A lei objetiva: a) aumentar a cobertura vegetal em sub-bacias hidrográficas; b) implantar corredores ecológicos; c) reduzir os níveis de poluição difusa em meio rural; d) difundir o conceito de manejo integrado de vegetação, solo e água; e e) garantir a sustentabilidade socioeconômica e ambiental das práticas implantadas. O meio para assegurar o alcance destes objetivos é o 
apoio financeiro aos proprietários rurais que cumpram metas de adequação ambiental.

Ao final de 2013, o projeto tinha estabelecido contratos com 161 proprietários, atingindo R $2.298 .102,00$ destinados exclusivamente ao PSA (PROJETO CONSERVADOR DAS ÁGUAS, 2014). O valor pago aos proprietários era de $\mathrm{R} \$ 210,00$ por hectare ao ano, tendo como base de cálculo o custo de oportunidade do principal uso da terra no município, a pecuária. $\mathrm{O}$ valor mensal recebido é relativo ao tamanho total da propriedade. Assinado o contrato de quatro anos, o proprietário deverá entrar em acordo com os técnicos do projeto sobre as ações de conservação ou restauração florestal, de conservação de solos e de saneamento rural que devem ser realizadas em sua propriedade (PEREIRA, 2013).

Os recursos financeiros para o PSA, em maior parte, são garantidos pelo Fundo Municipal de PSA e, em menor parte, via diferentes parcerias. A operacionalização do projeto é assegurada pelo Departamento Municipal de Serviços Urbanos e Meio Ambiente, que tem equipe e estrutura própria. A adesão ao projeto será efetivada se a propriedade rural estiver inserida em uma das sub-bacias priorizadas pelo projeto, sua área ser maior ou igual a dois hectares e ter outorga de uso da água (PEREIRA, 2013).

\subsection{Projeto Piloto no PCJ em Joanópolis e Nazaré Paulista (SP)}

Os municípios de Joanópolis e de Nazaré Paulista se situam na mesorregião Macro Metropolitana Paulista, distantes respectivamente cerca de 90 e 110 quilômetros da capital, São Paulo. Os dois municípios se localizam na Serra da Mantiqueira, próximos ao município de Extrema. Joanópolis tem pluviosidade média anual de $1.469 \mathrm{~mm}$ e Nazaré Paulista de $1.371 \mathrm{~mm}$ por ano (COBRAPE, 2010). Em 2007, Joanópolis possuía 39\% e Nazaré Paulista 49\% dos seus territórios ocupados por vegetação florestal nativa (UEZU et al., 2012).

Ambos os municípios integram os Comitês PCJ e estão inseridos na área de contribuição dos reservatórios do Sistema Cantareira. O projeto piloto PSA ocorre nas sub-bacias do ribeirão Cancã em Joanópolis e do ribeirão Moinho em Nazaré Paulista.

Em 2010, Joanópolis tinha população de 11.768 habitantes, considerada em sua totalidade como urbana (IBGE, 2011). Nazaré Paulista, em 2010, possuía
16.414 habitantes, $85 \%$ considerados residentes urbanos e $15 \%$ rurais (IBGE, 2011).

No meio rural destes municípios, predomina a monocultura de eucalipto, cuja cadeia produtiva é bastante estruturada e pouco regulamentada. Paralelamente, o turismo rural é consolidado por meio de dezenas de pousadas rurais, hotéis fazenda e marinas. A existência de represas e a proximidade com a RMSP favorecem a atração de um contingente populacional de novos moradores para residir e usufruir de suas áreas rurais.

Nestas localidades, o Projeto Piloto Produtor de Água no PCJ foi viabilizado pela Deliberação dos Comitês PCJ n. 51/06, que permitiu o uso de recursos da cobrança pelo uso da água nas Bacias PCJ para o PSA. O objetivo do projeto é aplicar o modelo provedor-recebedor, incentivando os proprietários rurais a contribuir com a proteção e recuperação dos mananciais através de pagamentos financeiros. Com adesão voluntária, o projeto visa restaurar o potencial hídrico e o controle da poluição difusa no meio rural. As intervenções focam a conservação dos recursos hídricos através de ações de proteção de fragmentos florestais, de restauração florestal e de conservação de solo (ANA, 2013).

O edital para a chamada dos proprietários foi aberto em 2009 e se encerrou em 2012. Ao longo deste período, 41 contratos foram assinados. Os proprietários interessados (pessoas físicas ou jurídicas) deveriam apresentar documentação pessoal e da posse do imóvel. Para os três anos do projeto, o valor aprovado para o PSA somou R\$395.250,00. Ademais, este projeto agregou parcerias que adicionam recursos financeiros para fins variados: implementação e manutenção de áreas de restauração florestal, construção de barraginhas, contratação de equipe técnica, apoio estrutural e operacional (PADOVEZI et al., 2013).

Os valores pagos aos proprietários seguem critérios quantitativos e qualitativos, transferidos semestralmente em função das práticas conservacionistas implementadas. Estas últimas tinham como base três parâmetros: a) o Percentual de Abatimento de Erosão, que é calculado através das perdas de solo antes e após a adoção das práticas de conservação ( $\mathrm{R}$ \$ 25,00 a $\mathrm{R} \$ 75,00$ por hectare ao ano); b) a Avaliação da Restauração Florestal, que tem como base a avaliação da qualidade da restauração após ser efetuada pelo projeto ( $\mathrm{R} \$ 83,00$ a $\mathrm{R} \$ 125,00$ por hectare ao ano); 
248 - Ruralidades e Política Ambiental: heterogeneidade socioeconômica e lógicas indiferenciadas dos projetos públicos de pagamento por serviços ambientais

Quadro 1. Perfil dos proprietários nos casos estudados, em 2013

\begin{tabular}{|l|c|c|c|c|}
\hline \multirow{2}{*}{ Condição } & \multicolumn{4}{|c|}{ Perfil dos proprietários } \\
\cline { 2 - 5 } & Agricultor familiar & Agricultor pluriativo & Morador & Não morador \\
\hline Residência & Permanente & Permanente & Permanente & Não residente \\
\hline $\begin{array}{l}\text { Principais fontes de } \\
\text { renda }\end{array}$ & Agropecuária & $\begin{array}{c}\text { Assalariamento/ } \\
\text { Aposentadoria }\end{array}$ & $\begin{array}{c}\text { Assalariamento/ } \\
\text { Aposentadoria }\end{array}$ & $\begin{array}{c}\text { Assalariamento/ } \\
\text { Iniciativa privada }\end{array}$ \\
\hline $\begin{array}{l}\text { Tempo de trabalho na } \\
\text { propriedade }\end{array}$ & Integral & Parcial & Ausente/Eventual & Ausente/Eventual \\
\hline Finalidade da produção & $\begin{array}{c}\text { Autoconsumo e } \\
\text { Mercado }\end{array}$ & $\begin{array}{c}\text { Autoconsumo e } \\
\text { Mercado }\end{array}$ & Autoconsumo & Mercado \\
\hline
\end{tabular}

Fonte: Pesquisa de campo (2013).

c) Conservação de Florestas, que tem como base o estágio sucessional da floresta protegida ( $\$ 25,00$ a $\mathrm{R} \$ 125,00$ por hectare ao ano) (ANA, 2013).

As entidades gestoras e executoras do projeto se reúnem na Unidade de Gestão do Projeto que é composta por representantes das seguintes instituições: The Nature Conservancy (TNC); da Câmara Técnica Rural dos Comitês PCJ; Agência das Bacias PCJ; Secretaria Estadual de Meio Ambiente de São Paulo; Secretaria Estadual de Agricultura e Abastecimento de São Paulo via Coordenadoria de Assistência Técnica Integral; World Wildlife Fund - Brasil; Agência Nacional de Águas (ANA); Associação Mata Ciliar; Iniciativa Verde; Fundação Banco do Brasil; Prefeitura Municipal de Nazaré Paulista; Prefeitura Municipal de Joanópolis e Prefeitura Municipal de Extrema (PADOVEZI et al., 2013).

\section{Perfil socioeconômico dos proprietários rurais}

Apesar das singularidades de cada localidade rural, existem algumas características daquelas consideradas neste estudo que as aproximam, dentre as quais se destacam: a) o relevo declivoso, em razão da localização dos municípios em regiões serranas; b) o regime pluviométrico, pelos volumes de chuvas anuais relativamente altos, o que se reflete na presença de uma densa rede hidrográfica; c) a proximidade de grandes centros urbanos e d) a presença de atrativos naturais, como belezas cênicas e clima ameno. De algum modo, são estas características ambientais que vêm atraindo novos moradores para o meio rural dos municípios onde os projetos de PSA-Água foram implantados, configurando uma heterogeneidade social que deve ser efetivamente considerada para as análises sociais.
O Quadro 1 apresenta os perfis identificados nos contextos estudados e as condições nas quais se enquadram.

Os "agricultores familiares"7 residem permanentemente e se dedicam integralmente ao trabalho produtivo na propriedade rural, tendo como principal fonte de renda a agropecuária (que inclui aqui a produção de eucalipto). Estas famílias podem contar eventualmente com a entrada de recursos financeiros por outras fontes, como aposentadoria, renda de aluguel e até o salário de algum membro da família, mas nunca superando $20 \%$ da renda total familiar. Neste perfil, é produzida a maior pauta produtiva, tanto para o autoconsumo familiar como para a comercialização em mercados. A reprodução social da família depende da produção e da comercialização dos produtos da agropecuária. No geral, são famílias que nasceram no local ou chegaram de alguma localidade próxima há mais de 30 anos.

Os "agricultores pluriativos" residem permanentemente na propriedade rural, mas a família obtém renda, principalmente, de atividades fora dela. No geral, são proprietários de pequenas parcelas que atuam como trabalhadores rurais diaristas ou empreiteiros, funcionários públicos, assalariados urbanos ou rurais e aposentados com capacidade de trabalho. Estas famílias se empenham em tempo parcial a atividades produtivas dentro da própria propriedade. Apesar de se dedicarem à produção para o autoconsumo e à comercializa-

7. Levou-se em considerou a Lei no 11.326 , de 24 de julho de 2006, que define como agricultor familiar aquele que: a) utilize predominantemente mão de obra da própria família nas atividades econômicas do seu estabelecimento ou empreendimento; b) tenha renda familiar predominantemente originada de atividades econômicas vinculadas ao próprio estabelecimento ou empreendimento; c) dirija seu estabelecimento ou empreendimento com sua família (BRASIL, 2006, p. 1). 
ção, essa produção é em menor escala de importância do que aquela dos agricultores familiares. No geral, são famílias do local ou da cidade, mas com vínculo anterior com a localidade, tendo o propósito de obter alguma renda da produção agropecuária.

Os "moradores" residem permanentemente na propriedade rural, mas praticamente não obtêm renda da agropecuária. A propriedade rural é utilizada como um lugar sobretudo de moradia. A renda familiar provém de aposentadorias por motivo de invalidez relativas a trabalhos urbanos e por salários obtidos na cidade pelo desempenho de atividades como de motorista, operário, comerciante, vendedor, bancário, professor ou empresário. O trabalho familiar na agricultura é inexistente ou eventual, devido à incapacidade física ou pouca afinidade com o trabalho agrícola. Portanto, produzem quase nada para o mercado e uma pequena pauta de produtos alimentares para o autoconsumo, sem dependência alguma desta produção. Estas famílias chegaram há poucos anos da cidade após obterem a aposentadoria ou são famílias locais em que os membros ativos migraram.

Os "não moradores" não residem de modo permanente na propriedade. Em certos casos, há uma família (do caseiro) que zela pela propriedade. A dedicação da família proprietária ao trabalho produtivo é inexistente ou eventual. Contudo, por meio da contratação de trabalhadores ou caseiros, há o investimento em atividades produtivas, principalmente, aquelas que demandam menos dedicação e trabalho. Por esta razão, há geração de renda na propriedade que, no geral, é pequena, mas que pode em alguns casos ser mais representativa. Investem em produzir para o mercado, mas pouco para o autoconsumo. São famílias urbanas mais abastadas que compraram o imóvel como um patrimônio e o usufruem de forma variada. Por vezes, trata-se de famílias do local que migraram e mantiveram a propriedade rural.
Estes perfis foram identificados em todos os casos estudados (Tabela 1). No universo de 77 entrevistas, o perfil de agricultor predomina, sendo que $40,2 \%$ dos entrevistados podem ser enquadrados como agricultores familiares e $18,2 \%$ como agricultores pluriativos. Os moradores perfazem 19,5\% e os não moradores, $22,1 \%$.

Para Carneiro (2012), a análise das ruralidades contemporâneas não pode ser orientada pelo simples reconhecimento da dualidade entre aqueles que podem ser chamados "de dentro" e aqueles "de fora" da localidade. As inter-relações entre eles promovem combinações muito mais diversas, não somente em relação à origem social, mas também pela posição no território, pelos valores e pelas maneiras de se apropriarem dos bens materiais e simbólicos das localidades rurais. De fato, considerar estas diferentes variáveis socioculturais leva à diluição da importância da variável espacial na diferenciação social de proprietários. Contudo, quando se considera as variáveis socioeconômicas para tal diferenciação, torna-se bastante claro, como aspecto central, o grau de dependência dos grupos familiares agrícolas em relação à terra. Para o agricultor familiar, a dependência é completa, pois a família reside, obtém renda, trabalha integralmente e garante a segurança alimentar da família dentro da sua propriedade rural. No outro extremo, o não morador não reside, não obtém renda e não trabalha na propriedade rural. Entre estes dois perfis, o morador também pode ser apresentado com tendo uma dependência mínima da propriedade rural para sua reprodução socioeconômica e o agricultor pluriativo, apesar de se dedicar à produção agropecuária, também não depende tanto dela para sobreviver.

Portanto, a diferenciação realizada confirma uma heterogeneidade socioeconômica relevante para a análise das transferências via PSA-Água. A relação de dependência socioeconômica do grupo agrícola familiar à terra se torna imprescindível para discutir sob a

Tabela 1. Distribuição (em percentual) dos perfis dos entrevistados nos casos dos projetos de PSA-Água, em 2013

\begin{tabular}{lcccc}
\hline \multicolumn{1}{c}{ Perfil } & Total & ProdutorES & Conservador & Projeto Piloto \\
\hline Agricultor familiar & 40,2 & 53,3 & 34,4 & 26,7 \\
Morador & 19,5 & 10,0 & 25,0 & 26,7 \\
Agricultor pluriativo & 18,2 & 16,7 & 18,7 & 20,0 \\
Não morador & 22,1 & 20,0 & 21,9 & 26,7 \\
Total & 100,0 & 100,0 & 100,0 & 100,0 \\
\hline
\end{tabular}

Fonte: Pesquisa de campo (2013). 
250 - Ruralidades e Política Ambiental: heterogeneidade socioeconômica e lógicas indiferenciadas dos projetos públicos de pagamento por serviços ambientais

ótica de justiça ambiental as transferências monetárias via projetos PSA-Água.

\section{Transferência monetária e perfil atingido}

Primeiramente, identificou-se que o projeto Conservador das Águas transferiu aos entrevistados, em média, 0,96 salário mínimo ${ }^{8}$ ao mês (R\$ 7.853,75 ao ano). No ProdutorES de Água, o montante transferido foi, em média, de 0,3 salário mínimo ao mês ( \$ 2.425,48 ao ano) e o Projeto Piloto repassou 0,16 salário mínimo ao mês ( $\mathrm{R} \$ 1.345,21$ ao ano).

A destinação dos pagamentos financeiros (PSA) por perfil de participante, exceto no Projeto Piloto, seguiram em maior parte para os agricultores familiares (Tabela 2). Porém, no montante geral dos projetos, os agricultores familiares receberam 36,4\% ( $\mathrm{R} \$ 469.787,61$ ) e os outros perfis, quase o dobro, $63,6 \%$ (R\$ 818.569,85).

No caso do projeto ProdutorES de Água, apesar de os agricultores familiares predominarem dentre os entrevistados e receberem o maior montante absoluto dos pagamentos, este grupo foi relativamente aquele que recebeu em média o menor pagamento anual, R\$ 1.873,90 (Tabela 3). Tal repartição indica que o esquema de pagamento do projeto não direcionou os maiores valores de pagamento aos agricultores familiares em relação aos outros perfis. Neste esquema, o valor do pagamento que considera variáveis como presença de cursos d'água com vegetação nativa, declividade do terreno e tamanho da área são consideradas acima de variáveis socioeconômicas. Portanto, os agricultores familiares não foram o alvo principal da política.

O esquema de pagamento do Conservador das Águas, que transfere um valor fixo ao beneficiário por hectare ao ano, é o único no qual o tamanho da propriedade tem influência direta sobre o valor a ser pago ao proprietário. Neste caso, o perfil de agricultor familiar também foi o que recebeu de modo absoluto o maior montante de pagamento do projeto (Tabela 2). Mas, relativamente, recebeu menos que o perfil de não morador (em média R\$ 10.864,57 ao ano). O perfil de agricultor familiar obteve, em média, R\$ 8.143,64 ao ano.

8. O salário mínimo vigente em 2013 era de $\mathrm{R} \$ 678,00$.
Aqui, vale ressaltar a desigualdade inerente a este esquema, que é referência nacional em termos de desenho e implementação do mecanismo de PSA-Água. Foi possível identificar que um morador entrevistado, proprietário de 200 hectares, dispôs para as ações conservacionistas 15 hectares de pastagem, o equivalente a 7,5\% da área total de sua propriedade. Por tal compromisso, ele recebia R\$ $3.200,00$ ao mês. Por outro lado, um agricultor familiar proprietário de 14 hectares abriu mão de 2,4 hectares de pastagens, o equivalente a $17 \%$ de sua propriedade. Neste caso, ele recebia apenas R\$ 255,00 ao mês. Neste desenho, mesmo se ações ambientais se limitam a uma pequena parte da propriedade, é seu tamanho total que determina o pagamento. Desta maneira, os maiores proprietários recebem mais, mesmo se sua contribuição seja menor, o que revela pouca preocupação com os aspectos redistributivos na concepção do dispositivo.

Apesar de estabelecer outro esquema de pagamento, que considera além da dimensão da área a ser conservada e restaurada, a quantidade e a qualidade das práticas de conservação, no Projeto Piloto, o perfil de não morador também recebeu a maior média anual R\$ 2.598,09, já os agricultores familiares embolsaram quase a metade disso, $\mathrm{R} \$ 1.793,37$ (Tabela 3).

Assim, o esquema de pagamento influi diretamente no montante médio recebido por cada perfil. No ProdutorES de Água, onde predomina o grupo de agricultor familiar, o esquema adotado não favoreceu o maior pagamento médio a este perfil. Pelo contrário, aqui se encontra o menor valor médio repassado. No Conservador das Águas, o maior pagamento se destinou, como já exemplificado, aos detentores das maiores propriedades, constituindo o grupo de não moradores. No Projeto Piloto, os proprietários de maiores áreas já conservadas foram favorecidos, caso dispostos a implementar o maior número de práticas conservacionistas. Novamente, os maiores beneficiários foram aqueles enquadrados no perfil de não moradores. Tais esquemas de pagamento coincidem com os que Martin-Ortega, Ojea e Roux (2014) encontraram analisando projetos de PSA-Água em 10 países da América Latina, onde quatro principais fatores incidem sobre o valor do pagamento: a) o tipo de ação conservacionista, b) as características da ocupação do solo, c) o número de ações a serem realizadas e d) o tamanho da área. Constata-se que os esquemas de pagamento dos projetos de PSA-Água não priorizam as variáveis 
Tabela 2. Valor recebido absoluto pelo contrato de PSA e percentual por perfil de proprietário

\begin{tabular}{|c|c|c|c|c|c|c|}
\hline \multirow{2}{*}{ Perfil/Projeto } & \multicolumn{2}{|c|}{ ProdutorES * } & \multicolumn{2}{|c|}{ Conservador ** } & \multicolumn{2}{|c|}{ Projeto Piloto * } \\
\hline & $R \$$ & $\%$ & $R \$$ & $\%$ & $R \$$ & $\%$ \\
\hline Agricultor familiar & $89.947,11$ & 41,2 & $358.320,00$ & 35,6 & $21.520,50$ & 33,2 \\
\hline Agricultor pluriativo & $65.225,22$ & 29,9 & $94.224,00$ & 9,4 & $5.685,00$ & 8,8 \\
\hline Morador & $18.615,81$ & 8,5 & $248.400,00$ & 24,7 & $6.531,00$ & 10,1 \\
\hline Não morador & $44.504,82$ & 20,4 & $304.208,00$ & 30,3 & $31.176,00$ & 48,0 \\
\hline Total & $218.292,96$ & 100,00 & $1.005 .152,00$ & 100,00 & $64.912,50$ & 100,00 \\
\hline
\end{tabular}

* Os contratos foram de três anos; ** Os contratos são de quatro anos.

Fonte: Pesquisa de campo (2013).

Tabela 3. Valor anual médio recebido pelos entrevistados, considerando o perfil dos participantes dos projetos de PSA-Água, em 2013

\begin{tabular}{lccc}
\hline \multirow{2}{*}{ Perfil/Projeto } & \multicolumn{3}{c}{ R\$/ano } \\
\cline { 2 - 4 } & ProdutorES & Conservador & Projeto Piloto \\
\hline Agricultor familiar & $1.873,90$ & $8.143,64$ & $1.793,37$ \\
Agricultor pluriativo & $4.348,35$ & $3.926,00$ & 544,25 \\
Morador & $2.068,42$ & $7.762,50$ & 631,67 \\
Não morador & $2.472,49$ & $10.864,57$ & $2.598,09$ \\
\hline
\end{tabular}

Fonte: Pesquisa de campo (2013).

socioeconômicas e culturais do estabelecimento rural, mas, sim, os aspectos quantitativos e qualitativos do ambiente físico.

De modo geral, pode-se observar que, relativamente, o perfil de não morador recebeu os melhores pagamentos médios dos projetos de PSA-Água. Os agricultores familiares, profundamente dependentes da agropecuária e da propriedade rural para sua reprodução social, podem ser posicionados como o segundo perfil melhor remunerado. Aqui, convém enfatizar que a maior parte dos recursos não chegou às mãos dos agricultores familiares. Os serviços hidrológicos, por serem influenciados em grande parte pelas condições existentes no meio rural, direcionam o PSA aos proprietários rurais, independente da relação que estabeleçam com a agricultura e com a propriedade rural. Torna-se, portanto, claro que a questão da redistribuição de recursos públicos aos grupos mais dependentes da terra não figurou como princípio orientador para o desenho dos projetos.

\section{Impacto do PSA sobre a renda familiar}

O potencial impacto do PSA sobre a redução da pobreza ganhou importância na literatura sobre o tema. Há o pressuposto de que populações pobres são rurais e, muitas delas, habitam locais marginais ao desenvolvimento econômico industrial, mas ricos em serviços ambientais, como áreas de florestas, de montanhas e de mananciais de recursos hídricos (ERWIN et al., 2008). Neste sentido, o Brasil é considerado como um país propício para a aplicação do mecanismo de PSA-Água visto seu potencial de causar efeitos positivos no bem-estar das populações rurais, já que apresenta altos índices de pobreza rural. Buscou-se aqui, a partir da renda familiar, analisar o impacto do PSA sobre as famílias beneficiadas.

Os documentos em torno dos Objetivos do Desenvolvimento do Milênio estabelecem duas linhas da pobreza. No Brasil, em 2013, uma pessoa extremamente pobre recebia ao mês até 0,1 salário mínimo e, em condição de pobreza, até 0,2 salário mínimo. ${ }^{9}$ A Tabela 4 mostra que em média nenhum perfil identificado em nenhum caso estudado se aproxima destes limites. Os participantes entrevistados não integram o quadro de pobreza rural.

9. É indicado como linha de extrema pobreza o limite de US\$ 1.25 ao dia por pessoa e, para a linha da pobreza, US\$ 2.00 ao dia por pessoa. Em 2003, US\$ 1.00 equivalia a $\mathrm{R}$ \$2,034 e o salário mínimo vigente era de $\mathrm{R} \$ 678,00$. 
252 - Ruralidades e Política Ambiental: heterogeneidade socioeconômica e lógicas indiferenciadas dos projetos públicos de pagamento por serviços ambientais

Tabela 4. Renda per capita anual média estimada e equivalência em salário mínimo (SM) ao mês, vigente em 2013

\begin{tabular}{lcccccc}
\hline \multirow{2}{*}{\multicolumn{1}{c}{ Projeto/Perfil }} & \multicolumn{2}{c}{ ProdutorES } & \multicolumn{2}{c}{ Conservador } & \multicolumn{2}{c}{ Projeto Piloto } \\
\cline { 2 - 7 } & Renda & $S M$ & Renda & SM & Renda & SM \\
\hline Agricultor familiar & $7.841,65$ & 1,0 & $13.781,82$ & 1,7 & $12.367,03$ & 1,5 \\
Morador & $8.979,58$ & 1,1 & $43.587,00$ & 5,4 & $5.669,38$ & 0,7 \\
Agricultor pluriativo & $20.228,92$ & 2,5 & $7.475,73$ & 0,9 & $12.342,57$ & 1,5 \\
Não morador & $103.744,15$ & 12,8 & $103.631,40$ & 12,7 & $156.684,25$ & 19,3 \\
\hline
\end{tabular}

Nota: Salário mínimo (SM) mensal vigente em 2013: R\$ 678,00.

Fonte: Pesquisa de campo (2013).

Entretanto, não há homogeneidade em termos de renda quando são observados os diferentes perfis. Os membros das famílias com dedicação estrita à agropecuária recebem entre 1 e 1,7 salário mínimo ao mês. Os não moradores apresentam as maiores rendas, chegando a mais de 12 vezes a dos agricultores familiares nos casos de Alfredo Chaves e do Projeto Piloto (12,8 e 19,3 salários mínimos respectivamente) e a sete vezes mais em Extrema (12,7 salários mínimos). Destaca-se que, no perfil de não morador, estão profissionais liberais, como advogados e engenheiros, funcionários de nível de gerência de bancos, proprietários industriais e de comércios. Trata-se de ocupações que conferem rendas elevadas em relação aos outros perfis identificados. Os outros dois perfis de participantes possuem renda que variam em cada caso considerado. No ProdutorES de Água, os agricultores pluriativos e os moradores recebem, em média, 2,5 e 1,1 salários mínimos, respectivamente. No Conservador das Águas, os moradores obtêm 5,4 salários mínimos e os pluriativos, 0,9. No Projeto Piloto, os agricultores pluriativos ganham 1,5 e os moradores 0,7 salário mínimo.

Estes números revelam que a heterogeneidade social das "ruralidades contemporâneas" implica na incorporação do componente de desigualdade econômica. Se no contexto do "novo rural", os sítios de recreio e os novos moradores expulsam as grandes culturas intensivas no uso de agrotóxicos (GRAZIANO DA SILVA, 1999), o clássico antagonismo entre latifúndio e pequenas propriedades familiares desaparece e a desigualdade no âmbito produtivo-tecnológico se torna menos evidente (BELIK, 2015), a nova configuração socioeconômica do rural não permite eliminar as desigualdades sociais. Os sítios de recreio com muros altos e câmaras de segurança, que protegem as luxuosas casas de veraneio passam a contrastar com os sítios dos agricultores familiares compostos por suas casas autoconstruídas ao lado de um pequeno curral, demarcando claramente "novas desigualdades". Assim, o "novo rural" ou as "ruralidades contemporâneas" não se livraram das velhas desigualdades.

Porém, as desigualdades socioeconômicas são invisíveis no âmbito da aplicação das políticas ambientais. O Código Florestal de 2012, apesar de ter flexibilizado as exigências para a preservação, considerando o tamanho das propriedades, trata todos os proprietários de imóveis rurais como iguais, estabelecendo regras para a conservação exclusivamente pelo tamanho da propriedade e por seus atributos ambientais (nascentes, rios, montanhas), desconsiderando as condições sociais, econômicas e culturais das famílias (nem sempre, aliás, proprietárias das terras nas quais produzem). Do mesmo modo, a aplicação do mecanismo de PSA-Água, fundado no apoio ao proprietário rural, invisibilizou as diferenças socioeconômicas dos atores e dos contextos rurais com vistas à conservação ambiental. Esta política de incentivo não se diferencia daquela regulatória no sentido de ter um caráter indiferenciado (desde a perspectiva dos perfis socioeconômicos do grupo meta).

Entretanto, mesmo identificando esta desconsideração, quando se analisa a transferência via PSA de modo proporcional à renda, percebe-se que os agricultores familiares em todos os projetos receberam transferências relativamente maiores do que os não moradores. Com base na Tabela 5, percebe-se que em média para os agricultores familiares, o PSA representou 23\% da sua renda no contexto do ProdutorES, 59\%, no Conservador, e 15\%, no Projeto Piloto, sendo que, para os não moradores, representou: 2,3\%; 10,5\% e $1,66 \%$ respectivamente.

Desse modo, a desigualdade de renda vai refletir no impacto do PSA sobre a renda familiar total. O Conservador das Águas apresentou a maior capaci- 
Tabela 5. Renda per capita anual média estimada e PSA médios anual equivalentes em salário mínimo (SM) ao mês, vigente em 2013

\begin{tabular}{lcccccc}
\hline \multirow{2}{*}{ Projeto/Perfil } & \multicolumn{2}{c}{ ProdutorES } & \multicolumn{2}{c}{ Conservador } & \multicolumn{2}{c}{ Projeto Piloto } \\
\cline { 2 - 7 } & Renda & PSA & Renda & PSA & Renda & PSA \\
\hline Agricultor familiar & 1 & 0,23 & 1,7 & 1,00 & 1,5 & 0,22 \\
Morador & 1,1 & 0,53 & 5,4 & 0,48 & 0,7 & 0,07 \\
Agricultor pluriativo & 2,5 & 0,25 & 0,9 & 0,95 & 1,5 & 0,08 \\
Não morador & 12,8 & 0,30 & 12,7 & 1,34 & 19,3 & 0,32 \\
\hline
\end{tabular}

Nota: Salário mínimo (SM) mensal vigente em 2013: R\$ 678,00.

Fonte: Pesquisa de campo (2013).

dade de melhorar a renda familiar dos agricultores. O pagamento derivado do projeto permitiu que $73 \%$ ( $N=32$ ) dos agricultores familiares e $40 \%$ dos agricultores pluriativos entrevistados tivessem entre $10 \%$ e $50 \%$ de sua renda anual familiar proveniente do PSA. Para os outros dois perfis, o PSA representou para a maioria dos entrevistados até $10 \%$ da renda familiar total (morador 88\%; não morador 86\%). No ProdutorES de Água, o PSA equivaleu para 70\% ( $\mathrm{N}=30)$ dos entrevistados, entre 0 e $10 \%$ da renda familiar anual. O Projeto Piloto foi o menos relevante: o valor pago correspondeu, para todos os perfis, a uma faixa de 0 a $5 \%$ da renda familiar anual.

Efetivamente, no caso em que o PSA atingiu os maiores valores (Conservador das Águas), houve uma contribuição mais expressiva do pagamento sobre a renda familiar do perfil de agricultor familiar. Tal contribuição não pode ser observada na renda do perfil de não moradores, que recebe renda familiar mais elevada. No Brasil, diferentes estudos revelam os impactos positivos que as transferências de renda para a agricultura familiar promovem em termos de segurança alimentar, da vitalidade de sistemas produtivos e da própria econômica local (RIBEIRO, 2007; DELGADO e CARDOSO JR., 2009). Estes efeitos dificilmente ocorrerão por meio de transferências destinadas aos não moradores, pela não vinculação entre família e produção agrícola e, provavelmente, pela mobilidade locacional dos recursos recebidos, que podem ser gastos fora da localidade onde os projetos ocorrem.

Na prática, foi difícil identificar com exatidão como os recursos provenientes do PSA foram utilizados pelos beneficiários, pois são valores que se integram no montante total do orçamento familiar sem discriminação de seu uso. De todo modo, conforme declarado, há mais recursos para custeio e investimento. Para os três casos estudados, o custeio com despesas recorrentes foi a principal forma de uso (87\%). Os principais itens de despesas foram alimentação, combustível, insumos agrícolas, impostos, empregados, taxas, dívidas, mensalidade escolar e lazer. Dentre os investimentos (13\% dos proprietários), predominam a construção ou reforma de casas ou benfeitorias na propriedade.

Por outro lado, $34 \%(\mathrm{~N}=77)$ dos entrevistados informaram ter utilizado o pagamento diretamente na atividade produtiva: no caso do ProdutorES de Água, $68 \%(\mathrm{~N}=30)$ dos entrevistados afirmaram ter utilizado para este fim e, deste total, $63 \%(\mathrm{~N}=19)$ são agricultores familiares. Apenas $16 \%(\mathrm{~N}=19)$ são não moradores. $\mathrm{O}$ uso direto para o fim produtivo, nos casos do Conservador das Águas e Projeto Piloto, foi menos expressivo (17\% e $13 \%$ respectivamente), mas se concentrou no perfil de agricultor (familiar e pluriativo). Nestes últimos casos, apesar de a agropecuária ser desenvolvida sem muitos investimentos e de os agricultores familiares declararem aplicar diretamente pouco os recursos do PSA em seus sistemas produtivos, ressalta-se que toda a dinâmica de organização do orçamento familiar gira em torno da atividade agropecuária, condição que não condiz com os outros perfis, pois a atividade produtiva agropecuária não tem centralidade para a reprodução social familiar.

\section{Conclusões}

Nos casos estudados, os projetos PSA foram implementados em realidades que podem ser identificadas como "novo rural" ou "ruralidades contemporâneas". Estes locais estão próximos a grandes centros urbanos e têm características ambientais que vêm atraindo novos moradores com trajetórias essencialmente urba- 
254 - Ruralidades e Política Ambiental: heterogeneidade socioeconômica e lógicas indiferenciadas dos projetos públicos de pagamento por serviços ambientais

nas. Por serem localidades estratégicas à conservação de mananciais hídricos, tornaram-se alvo das políticas de PSA-Água.

Nessas localidades, é evidente a existência de proprietários rurais com perfis socioeconômicos diferenciados. O grau de dependência da família em relação à propriedade rural para sua reprodução social é um componente central desta diferenciação. A partir da nossa amostra, apesar da predominância do perfil de agricultor familiar, os perfis de agricultor pluriativo, morador e não morador ocupam lugar nestas localidades rurais. Portanto, tal diferenciação foi fundamental para analisar a distribuição de recursos financeiros efetivados pelos projetos PSA aos agentes privados da conservação ambiental.

Partindo dessa diferenciação, de modo absoluto, os projetos Conservador das Águas e ProdutorES de Água destinaram o maior montante de recursos ao pagamento de agricultores familiares, o que não ocorreu com o Projeto Piloto, que direcionou a maior parte dos PSA aos não moradores. No entanto, os dados relativos revelam que o Projeto ProdutorES destinou o menor valor médio aos agricultores familiares e o Conservador das Águas um valor médio abaixo do que foi transferido aos não moradores. Os critérios de pagamento são determinantes para a forma como os recursos via PSA serão distribuídos. Com efeito, os projetos não estabelecem que os proprietários rurais mais dependentes da terra recebam os melhores pagamentos. Ao contrário, são os proprietários menos dependentes da propriedade rural, com as rendas mais elevadas (quando não com mais terras) que captam a maior parte dos recursos destinados via PSA-Água. Portanto, nossos resultados não indicam compromissos entre objetivos ambientais e socioeconômicos.

No entanto, relativamente às respectivas rendas, os agricultores familiares receberam transferências via PSA significativamente maiores que os não moradores, nos três casos analisados. Tais transferências financeiras promoveram, assim, impactos expressivos sobre a renda familiar dos agricultores. Assim, apesar da ausência de preocupação com a condição socioeconômica dos proprietários para aplicar o PSA, seus efeitos foram relativamente positivos em transferir renda aos agricultores familiares.

De todo modo, conclui-se que são duas as principais orientações no âmbito dos projetos que permitem interpretar uma ausência de preocupação com a condição socioeconômica dos participantes na distribuição dos pagamentos. Em primeiro lugar, ao priorizar as dimensões físicas do ambiente para definir o valor do pagamento, este último é destinado, em valor anual médio, em maior proporção ao grupo social com maior renda e menos dependente na propriedade rural para seu modo de vida. Em segundo lugar, ao assumir indiferenciadamente o estatuto de proprietário rural como público-alvo dos projetos ocorre uma invisibilidade da heterogeneidade socioeconômica, e também sociocultural, das novas realidades rurais. Entende-se que para garantir um efeito redistributivo mais favorável aos agricultores mais dependentes da terra, as políticas analisadas teriam que mobilizar um conjunto diferente de critérios para a alocação dos pagamentos, incluindo um reconhecimento mais explícito das heterogeneidades socioeconômicas e produtivas locais.

\section{Referências}

ACSELRAD, H. Políticas Ambientais e construção democrática. In: VIANA, G., SILVA, M. e DINIZ, N. O desafio da sustentabilidade: um debate socioambiental no Brasil. São Paulo: Editora Perseu Abramo, 2001, p. 75-96.

ACSELRAD, H. Ambientalização das lutas sociais o caso do movimento por justiça ambiental. Estudos Avançados, São Paulo, v. 24, n. 68, p. 103-119, 2010.

ALMEIDA JR, A. R. e ANDRADE, T. N. Publicidade e ambiente: alguns contornos. Ambiente $\mathcal{E}$ Sociedade, Campinas, v. 10, n. 1, p. 107-120, jan./jun. 2007.

ANA - Agência Nacional das Águas. Portaria n. 196, de 30 de agosto de 2013. Aprova, na forma do Anexo, o Manual Operativo do Programa Produtor de Água [...]. Disponível em: < http://produtordeagua.ana.gov.br $>$. Acesso em: 10 jan. 2014.

ASSUMPÇÃO RODRIGUES, M. M. Políticas Públicas. São Paulo: Publifolha, 2010.

BELIK, W. A heterogeneidade e suas implicações para as políticas públicas no rural brasileiro. RESR, Piracicaba, v. 53, n. 1, p. 9-30, jan./mar. 2015.

BELOTE, T. S. et al. Projeto produtores de água: uma nova estratégia de gestão dos recursos hídricos através do mecanismo de pagamento por serviços ambientais. OLAM: Ciência \& Tecnologia, Rio Claro, v. 8, n. 3, p. 48-67, jul./dez. 2008.

BRASIL. Lei n. 11.326 de 24 de julho de 2006. Estabelece as diretrizes da Política Nacional da Agricultura Familiar 
e Empreendimentos Familiares Rurais. Disponível em: $<$ http://www. planalto.gov.br/.../L11326.htm>. Acesso em: 29 mar. 2014.

. Lei n. 12.651, de 25 de maio de 2012. Dispõe sobre a proteção da vegetação nativa [...]. Disponível em: <http://www.planalto.gov.br/ccivil_03/_ato20112014/2012/lei//12651.htm > . Acesso em: 11 mar. 2014.

CARNEIRO, M. J. Ruralidades contemporâneas: modos de viver e pensar o rural na sociedade brasileira. Rio de Janeiro: Mauad X, FAPERJ, 2012. 268p.

COBRAPE - Companhia Brasileira de Projetos e Empreendimentos. Plano das bacias hidrográficas dos Rios Piracicaba, Capivari e Jundiaí 2010 a 2020: relatório síntese. São Paulo: Neoband Soluções Gráficas, 2010.

DAILY, G. C. Introduction: what are ecosystem services? In: __ Nature's services: societal dependence on natural ecosystems. Washington: Island Press, 1997, p. 1-10.

DELGADO, G. C. e CARDOSO JR. J. C. Universalização de direitos sociais no Brasil: a previdência rural nos anos 90. In: LEITE, S. (Org.). Políticas públicas e agricultura no Brasil. 2. ed. Porto Alegre: Editora da UFRGS, 2009, p. 227-252.

DIEGUES, A. C. O mito moderno da natureza intocada. 3. ed. Campinas: Hucitec, 2001.

ENGEL, S., PAGIOLA, S. e WUNDER, S. Designing payments for environmental services in theory and practice: an overview of the issues. Ecological Economics, Philadelphia, v. 65, p. 663-674, 2008.

ERWIN, H., BULTE, L., STRINGER, R. e ZILBERMAN, D. Payments for ecosystem services and poverty reduction: concepts, issues, and empirical perspectives. Environment and Development Economics, Cambridge, v. 13, p. 245-254, 2008.

ESPÍRITO SANTO. Lei n. 8.995, de 22 de setembro de 2008. Institui o Programa de Pagamento por Serviços Ambientais - PSA e dá outras providências. Disponível em: <http://www.meioambiente.es.gov.br/>. Acesso em: 15 nov. 2013.

FERRARO, P. J. e KISS, A. Direct payments to conserve biodiversity. Science, New York, v. 298, p. 1718-1719, nov. 2002.

FROEHLICH, J.M. e MONTEIRO, R. C. Transformações semânticas recentes do "termo rural": uma leitura a partir da perspectiva urbana. Raízes, Campina Grande, v. 21, n. 2, p. 304-312, jul./dez. 2002.

GRAZIANO DA SILVA, J. O novo rural brasileiro. Campinas, SP: Unicamp. IE, 1999. 153p. (Coleção Pesquisas, 1)
HOEFFEL, J. L., FADINI, A. A. B. e SUAREZ, C. F. S. "The Nature We All Want" - Influences of São Paulo Metropolis on Tourism Development in the Bragantina Region, São Paulo, Brazil. Tourism and Hospitality Planning \& Development, London, v. 6, n. 3, p. 191-205, 2009.

IBGE - Instituto Brasileiro de Geográfia e Estatística. Cidades, 2011. Disponível em: <www.ibge.gov.br>. Acesso em: 2 mar. 2012.

IEMA - Instituto Estadual de Meio Ambiente. Região Hidrográfica do Rio Benevente, 2014. Disponível em: $<$ http://www.meioambiente.es.gov.br/>. Acesso em: 27 jan. 2014.

IPEA - Instituto de Pesquisa Economica Aplicada. Código Florestal: implicações do PL 1876/99 nas áreas de Reserva Legal. Rio de Janeiro, n. 96, 2011. 23p.

MALUF, R. S. A multifuncionalidade da agricultura na realidade rural brasileira. In: CARNEIRO, M. J. e MALUF, R. S. (Orgs.). Para além da produção: muntifuncionalidade e agricultura familiar. Rio de Janeiro: Mauad X, 2003, p. 135-152.

MARTIN-ORTEGA, J., OJEA, E. e ROUX, C. Payments for water ecosystem services in Latin America: a literature review and conceptual model. Ecosystem Services, Wageningen, v. 6, p. 122-132, 2014.

MILLENIUM ECOSYSTEM ASSESSMENT. Ecosystem and human well-being: synthesis. Washington: Island Press, 2005. 137p.

MURADIAN, R. et al. Reconciling theory and practice: An alternative conceptual framework for understating payments for environmental services. Ecological Economics, Philadelphia, v. 69, p. 1202-1208, 2010.

NUSDEO, A. M. O. Pagamento por serviços ambientais: sustentabilidade e disciplina jurídica. São Paulo: Atlas, 2012. 179 p.

PADOVEZI, A. Difusão e Experimentação de um Sistema de Pagamentos por Serviços Ambientais para restauração da "saúde ecossistêmica" de microbacias hidrográficas dos mananciais da sub-bacia do Cantareira. Atibaia: TNC, 2013. p. 25. (Terceiro Relatório Executivo do Projeto Produtor de Água no PCJ).

PAGIOLA, S., ARCENAS, A. e PlATAIS, G. Can payments for environmental services help reduce poverty? An exploration of the issues and the evidence to date from Latin America. World Development, Philadelphia, v. 33, n. 2, p. 237-253, 2005.

PAGIOLA, S., GLEHN, H. C. e TAFFARELLO, D. Introdução. In: Experiências de pagamento por 
256 - Ruralidades e Política Ambiental: heterogeneidade socioeconômica e lógicas indiferenciadas dos projetos públicos de pagamento por serviços ambientais

serviços ambientais no Brasil. São Paulo: SMA-SP/CBRN, 2013, p. 17-27.

PASCUAL, U. et al. Social equity matters in Payments for Ecosystem Services. Bioscience, London, v. 64, n. 11, p. 1027-1036, 2014.

PEREIRA, P. H. Projeto Conservador das Águas - Extrema. In: PAGIOLA, S., GLEHN, H. C. e TAFFARELLO, D. (Orgs.). Experiências de pagamento por serviços ambientais no Brasil. São Paulo: SMA-SP/CBRN, 2013, p. 29-40.

PROJETO CONSERVADOR DAS ÁGUAS 9 ANOS. Extrema: Prefeitura do Município de Extrema, 2014. 1 folder.

RIBEIRO, E. M. Feiras do Jequitinhonha: mercados, cultura e trabalho de famílias rurais no semi-árido de Minas Gerais. Fortaleza: Banco do Nordeste e Universidade Federal de Lavras, 2007. 246p. (Coleção BNB Projetos Sociais)

RICHARDSON, R. J. Pesquisa social: métodos e técnicas. 2. ed. São Paulo: Atlas, 2010. 334p.
SASTOQUE, M. J. M. Una Tipología de los Nuevos Habitantes del Campo: aportes para el estudio del fenómeno neorrural a partir del caso de Manizales, Colombia. RESR, Piracicaba/SP, v. 51, supl. 1, p. S031-S048, 2013.

SOSSAI, M. F. et al. Políticas públicas do estado do Espírito Santo para adequação ambiental e socioeconômica de propriedades rurais como estratégia de ampliação da cobertura florestal. Informe Agropecuário, Belo Horizonte, v. 33, n. 271, p. 7-13, nov./dez. 2012.

SPAROVEK G. et al. A revisão do Código Florestal Brasileiro. Novos Estudos, São Paulo, v. 69, p. 111-135, 2011.

UEZU, A. et al. Projeto Semeando Água: Pagamento por Serviços Ambientais no corredor CantareiraMantiqueira. Nazaré Paulista: Instituto de Pesquisas Ecológicas, 2012. 63p. Relatório final Projeto Mata Atlântica II, 2010.

WUNDER, S. When payments for environmental services will work for conservation. Conservation Letters, Washington, v. 6, n. 4, p. 230-237, jul./ago. 2013.

Todo o conteúdo deste periódico, exceto onde estiver identificado, está licenciado sob uma Licença Creative Commons (cc by 4.0) 